Meta

Journal des traducteurs

Translators' Journal

\title{
Early Years with the Inuit Interpreters: Recollections and Comments from the Sidelines
}

\section{S. T. Mallon}

Volume 38, numéro 1, mars 1993

La traduction et l'interprétation dans le nord du Canada

Translation and Interpretation in Northen Canada

URI : https://id.erudit.org/iderudit/003544ar

DOI : https://doi.org/10.7202/003544ar

Aller au sommaire du numéro

Éditeur(s)

Les Presses de l'Université de Montréal

ISSN

0026-0452 (imprimé)

1492-1421 (numérique)

Découvrir la revue

Citer cet article

Mallon, S. T. (1993). Early Years with the Inuit Interpreters: Recollections and Comments from the Sidelines. Meta, 38(1), 25-30.

https://doi.org/10.7202/003544ar
Résumé de l'article

L'article décrit le développement, entre 1974 et 1987, de l'interprétation en inuktitut. On présente les diverses difficultés rencontrées depuis la création du "Corps des interprètes", les actions entreprises pour les corriger et les réalisations de cette période. On traite également d'interprétation consécutive et simultanée et des problèmes de compréhension et de réception spécifiques à l'inuktitut. On examine enfin le rôle de l'interprète en tant que communicateur. 


\title{
EARLY YEARS WITH THE INUIT INTERPRETERS: RECOLLECTIONS AND COMMENTS FROM THE SIDELINES
}

S. T. MALLON

Iqaluit, Northwest Territories, Canada

\begin{abstract}
Résumé
L'article décrit le développement, entre 1974 et 1987, de l'interprétation en inuktitut. On présente les diverses difficultés rencontrées depuis la création du «Corps des interprètes», les actions entreprises pour les corriger et les réalisations de cette période. On traite également d'interprétation consécutive et simultanée et des problèmes de compréhension et de réception spécifiques à l'inuktitut. On examine enfin le rôle de l'interprète en tant que communicateur.
\end{abstract}

\begin{abstract}
This text discusses some of the developments which occurred in the field of Inuktitut interpreting from 1974 until 1987. It outlines the problems which were encountered and describes the steps taken to correct them. Specific comments on topics such as consecutive vs. simultaneous interpretation, comprehension, problems with input and the role of the interpreter as communicator are also discussed.
\end{abstract}

When the Interpreter Corps was founded in a blaze of publicity in 1973, I was working for the Department of Education on a program of Inuktitut as a Second Language. I was keenly interested in the challenges faced by the new organization, especially the linguistic ones. However, language issues seemed to carry little weight in planning and organization during the first year of the Corp's existence. The Corps was placed in the Department of Information; the man chosen to be responsible for training the new interpreters was a unilingual newspaper reporter, a recent immigrant from Britain whose activities had caught the Commissioner's attention. The assumption seemed to be that as long as the recruits were native speakers of a native language, the only further language training they needed was in English. There were a few lectures given by passing specialists, but the bulk of the training given was on the structure and operations of the various departments of the Government of the NWT. In a year or two the situation had changed. The newspaperman had moved on. For administration purposes he had been replaced by a long-term GNWT employee, Lloyd Dahl. For the bulk of the instruction of the Inuit interpreters the Department of Personnel arranged the secondment from Education of Peter Balt, an Eastern Arctic teacher and principal who had experience working on Inuktitut materials with Inuit instructors. A year or so later, in the winter of 1976, I believe, I arranged part-time release from my work at Education to take responsibility for language and interpreting/translation instruction. At that time, in the mid and late seventies, I also attended several Word Conferences organized by and for Inuit interpreters. Later, in 1987 and 88, I taught several linguistic programs to the Inuit interpreters.

That is the background. Before I make any specific comments on the training and the work of Inuit interpreter/translators I would like to comment on two further points: the "ideal" interpreting/translation program as set up in the southern world, as compared with the situation in the NWT in 1973 and the nature of the Inuktitut language. 


\section{IDEAL MODEL OF INTERPRETING / TRANSLATING PROGRAMS}

In the southern world, which certainly includes Europe as well as Canada, the ideal student for an interpreting / translating program is a mature well-educated individual, preferably already with a degree, who already has a considerable degree of fluency in the second language. Typically, professional training at the post-graduate level concentrates on:

- rigorous language work in the mother tongue and in the target languages;

- practical training in professional techniques;

- professional behaviour and ethics;

- continuation of background education, with an emphasis on those relevant to eventual specialization;

- courses specialized in law, medicine, public administration etc.

After their training, professional interpreters normally expect to work from the second language (the " $B$ " language) into the strongest language (the " $A$ " language).

In 1979 I attended a conference at Aarhus, in Denmark. I can remember the pride with which the interpreter, a man my own age, displayed his official interpreter's card, which listed both Danish and English as "A" languages, a singular distinction earned by his cross-cultural birth and upbringing.

Furthermore, professional southern interpreters and translators tend to be specialists. They specialize not only as interpreters or translators, but also in their fields of expertise.

\section{REALITY (YEAR 1973)}

Reality in the NWT in 1973 was considerably different. There was no pool of Inuit university graduates. There were very few Inuktitut-speaking high school graduates. For years most recruits into the program were mature adults who had left school early and whose qualifications were all based on experience, often in the lower echelons of government service. Since there are very few southerners with any degree of fluency in Inuktitut, and certainly none in the Interpreter Corps in the first few years, the Inuit interpreters were expected to interpret both to and from English. There was no opportunity to specialize. An interpreter would be at a desk translating a medical handbook in January, behind a microphone doing simultaneous interpretation at the Legislative Assembly in February, and travelling with the court party through the High Arctic in March.

\section{THE NATURE OF INUKTITUT AND THE ROLE OF LINGUISTIC UNDERSTANDING}

\section{Morphology}

Inuktitut is at once complex and logical. It relies heavily on a very precise set of patterns for building words, and on another meticulous set of rules for constructing sentences. The word-building patterns can often provide meaning even when translated item by item into English:

$\begin{array}{lcccc}\text { inuk } & \text { person } & \text { iglu } & \text { house } & \text { uumajuq } \\ \text {-liri- } & \text { work with } & -j i & \text {-er, one } & \text { whose job it is to } \\ \text { inuliriji } & \text { person/work with/er } & \text { social worker } \\ \text { igluliriji } & \text { house/work with/er } & \text { housing officer } \\ \text { uumajuliriji } & \text { animal/work with/er } & \text { wildlife officer }\end{array}$

Furthermore, not only is Inuktitut much more regular in its word-building patterns than English, it also makes much greater use of them. English is so accustomed to wordborrowing that we even borrow back Japanese transformed borrowings from English, as 
in the recent arrival on our shores of the word "salaryman." Inuktitut however, even today, has a tendency to create functional descriptions of imported items. Louis-Jacques Dorais has illustrated and quantified this tendency in "Uqausigusiqtaat: an Analytical Lexicon of Modern Inuktitut in Quebec/Labrador." In the Hudson Strait dialect, for example, of 1,355 new designants, only $5.09 \%$ were borrowings, $77.20 \%$ were lexicalizations, descriptions using the word-building process. Furthermore, $58.60 \%$ of these were functional descriptions, rather than descriptions by appearance. The point is that this reliance on the innate processes of the language rather than borrowing is not the result of dictats from an "Académie Esquimaude", or a conscious linguistic policy. It is inherent in the way Inuit use the resources of their language.

This tremendous morphological power has obvious advantages in the world of interpretation and translation. Both interpreters and their public share a tradition of ad hoc creation of complex definitive labels. Some are simply descriptive, as in the Inuktitut names of many embarrassed white residents, but many are functional. The translation, and the reception, of English technological terms is not therefore as much of a burden as is so often suggested. In fact, since Inuit terms are meaningful, and are expected to be meaningful, an unsophisticated audience in the Keewatin might have less trouble with terminology than an audience in rural Saskatchewan. Furthermore, the morphological processes in Inuktitut are not only flexible but also continuous. A year or so ago an article in the oracular Globe and Mail remarked on the plethora of terms used to describe AIDS. If uniformity is the aim, that is a defect. But the fertility of Inuktitut morphology means that once an interpreter or translator knows the point of view of the client, she can produce a term expressive of that orientation, stressing the causes of the syndrome, or its effects, or, what may be most important in the context of public health, the fact that at the moment it is incurable and fatal.

This morphological creativity also had at least two disadvantages.

- It was easy, and therefore tempting, to reinvent the wheel every time the need arose for a round revolving object. I don't know the present status of the Word Bank, a compendium of terms developed by interpreters and translators during their work. It may be that it is now an organized data bank which interpreters routinely consult and update. In the early years a translator would find it easier to redefine a technical term that to scurry around trying to find what someone else had used in a similar situation a month or so earlier.

- The second disadvantage stems from the laudable tendency in Inuktitut to produce a label which is a definition. Meanings tend to accumulate around English words through a process based more on historical accident than on logic. Camera comes from camera oscura "chambre obscure: dark room" reflecting the early experiments involving pricking pinholes in the blinds of otherwise totally darkened rooms. The Inuktitut translation is ajiliuruti: ajii image; -liuq- make; -uti instrument. This tendency is obviously a healthy one, but when taken to extremes the translator is driven by the ideal of one-word instant and complete definitions. I can remember a moment during a word conference on metrification when every translator in the room was struggling with the basic definition of meter (meter? metre?) so as to produce the ideal Inuktitut translation. We finally agreed that this was one case where in the name of international harmony we could join Finnish, Swahili, Chinese and Malay and simply transliterate the word.

In practice, of course, the interpreter usually explains a new term when it first comes up, with possibly a further remark or two on its next couple of appearances. The more clues the Inuktitut term gives to the meaning of the word, the better, but the word is not the dictionary entry. 
This matter of terminological precision is vital. For example, the usual translation of Land Claims was nunataarasuarniq: nuna land; -taaq-acquire; -rasuaq-try; -niq -ing: trying to acquire land. I was at a meeting once where the Povungnituk delegates urged the term nunaqarnirarniq: nuna land; -qaq-have; -niraq- state; -niq-ing: stating that we have the land: it's ours to start with, not something we are trying to acquire. The semantic overtones of many such translations require a sophisticated sensitivity in the professional translator.

\section{Syntax}

The sentence structure of Inuktitut, however, does not map so easily on to English, or indeed many of the other languages southerners are accustomed to:

I come from the school now.

Maintenant je viens de l'école.

Jeg kommer nu fra skulen.

Syandzai wo tsung sweijau hwei lai.

now I from school come

Ima gakko kara kimasu.

now school from (I)come

\begin{tabular}{llllll}
\multicolumn{2}{l}{ ilinniarvingminngaaliqtunga } & & & & \\
ilinniaq + & vik + & mit + & nngaaq + & liq + & junga \\
learn & place & from & verbalizer & now & $I$
\end{tabular}

That's a simple statement. Add a complex clause or two and the structures vary so greatly that there is no il n'y a pas opportunity d'opportunité to translate de traduire word by word mot par mot. Of course good interpreters do not translate that way, in any language. They decode a couple of sentences in Language B, store the essential meaning, and encode that meaning in Language A. But it does not seem unreasonable to suggest that similarities in structure aid this process, while extreme divergences in structure impede it.

\section{Argument for Linguistic Training}

These two factors, the productivity of the morphological processes, and the exoticism of the syntax, affect the training and the performance of Inuit interpreters. There is therefore a strong argument for including a linguistic component to any comprehensive training program for interpreter/translators. Add a third factor: the keen interest shown by Inuit students in the apparently dry subjects of phonology, morphology and syntax. Unfortunately, there is a regrettable tendency to import southern specialists in general language work, and heed their uninformed strictures against grammar. This is an attitude rooted in the nature of the English language, and in the irrelevant history of English language teaching in high schools during the thirties and forties. Linguistic study is not the most essential part of a training program for interpreter/translators, but it is essential.

\section{COMMENTS FROM PERIOD AS TRAINER}

I am well aware of the criticisms levelled against high school education in North America in general, and in the North in particular, criticisms to which I have contributed on occasion. But I have also noticed, in the North and Southeast Asia, that some changes seem to take place in the thinking patterns of some of those who sit through a year of grade eleven. Generally speaking, it is easier to teach generalizations and abstractions to such students. In the mid-seventies few interpreter trainees had that background, and the lack of it did make for difficult sledding at times. 


\section{Comprehension}

One phenomenon surprised me at first, and then alarmed me. It was in connection with the two kinds of interpretation, consecutive and simultaneous. In consecutive interpretation the speaker produces a sentence or two, and then pauses while the interpreter translates. Obviously novice interpreters prefer the speaker to produce comparatively short utterances between pauses. Experienced interpreters prefer longer utterances, not simply out of bravado, but because they want enough information to realize the speaker's intentions as well as his momentary utterances. In simultaneous interpretation the speaker talks without artificial pauses, while the interpreter, usually through some electronic system, processes and produces an interpretation a phrase or a sentence or two in arrears.

Once again, the experienced interpreter prefers a lag that is terrifying to the novice. It is incredible to observe such an expert at work. At any one instant the interpreter is receiving and stowing the present flow of words, and retrieving and processing the previous set.

I expected novices to find consecutive interpretation easier to deal with than simultaneous. In fact our training syllabus presented the skills in that order. The students, however, often claimed the opposite. Then I found out why. To make a show of consecutive interpretation you have to remember at least one phrase or sentence at a time. To remember that one phrase or sentence you have to understand it. However you can make a tremendous show of simultaneous interpreting if you rattle off some sequence of Inuktitut morphemes in response to each English phrase that flashes past, whether those sequences of Inuktitut combine to form sense or nonsense. That was when I began to realize the depth of the task of training interpreter/translators, and to realize my shortcoming as a professional educator, but not a professional interpreter/translator. Luckily the Department of Communications did arrange for workshops with members of the Bureau of Translation in Ottawa. The students were enthusiastic about these workshops, almost as much as I was.

\section{Achievements}

The load of expectations placed on those early interpreters was unrealistic. We know the standard of education and training demanded of southern interpreters. With only a fraction of those advantages, the Interpreter Corps was given equivalent tasks to perform, in languages where technical terms had to be created on the run. When it was announced that equipment for simultaneous interpretation was being acquired for the Legislative Assembly, I was convinced that we were heading for an expensive and embarrassing debacle. And I was wrong. There were a few crises, which seemed disastrous at the time, but within a few months... well, a year or two... the experienced interpreters were handling legislative sessions with aplomb, and had also learned how to initiate trainees into the system with the minimum of stress.

There was a great deal of intelligent effort that went into the training and organization of the Interpreter Corps, but the bulk of the credit has to go to those young native people who rose to a challenge that by all informed judgment should have been beyond them. Frankly, I was surprised, but more tellingly, so were the professionals from the Bureau of Translation who came up to give workshops and to observe the interpreters in action.

\section{The Problem of Input}

One other problem must be mentioned, a problem that has not yet been solved. When we look at the work of interpreters and translators we tend to judge the process by the quality of the output. In a bureaucracy most problems start earlier, with the quality of the input. This is much more serious with translation than with interpretation. Interpreters have much more control over input, and many more informal opportunities to add footnotes for the benefit of the audience. Experienced and confident interpreters are quite 
prepared to tell a precipitate speaker to slow down, even if he is Irish, or to interrupt a convoluted paragraph to ask for clarification. In fact, I have seen young bureaucrats receive the kind of tutorial editing that was obviously lacking in their university composition classes: the effects can only have been beneficial.

And there was the case of the Head of Wildlife who began the evening with an aside to his interpreter, "I always like to start with a little joke, so be sure to translate this. Ladies and gentlemen, polar bears operate in a very cold environment, but the topic of polar bears is a very hot one, heh-heh" ...pause, while the interpreter grappled with this gem. "Go on, translate it." The interpreter pondered a moment, and addressed the audience, "This man has tried to say something funny, but it doesn't make any sense in Inuktitut. So please laugh when I tell you to, now!' Laughter, and the Head of Wildlife says to his interpreter, "See, I told you that would get them relaxed and receptive."

But translators have no such control. A bureaucrat sits at his desk in an office building, with no image of his intended audience. He writes in the tribal style "Inter-office obfuscational memorandible" or rather "obliviscandible". At some stage it is decided that the result should be formulated in Syllabics, giving therefore visible proof of the government's desire to communicate. The document is sent directly to the native translator.

Let's pause for a moment to consider the translator's responsibility. The responsibility of a literary translator is to transmit as much as possible of the style as well as the content of the original, gravitas from Latin orations, pithiness from Chinese poetry, discursive connectedness from Russian novelists. But no translator could feel any pride in a passage that reflected the qualities of government prose: circumlocution, third-level abstractions, and in many cases, the deliberate attempt to conceal and confuse rather than reveal and clarify. So native translators have a twofold task: first they must try to understand what the writer is trying to say, or should have said; then they must turn that understanding into a document which will in turn be understood by the inhabitants of a small village on the shores of Hudson Bay. I used to tell civil servants to imagine that their public documents were going to be read aloud at a village meeting in a Newfoundland outport some thirty years ago, and that they would have to face the rage that resulted from any cognitive confusion that resulted. Too often, of course, the translator compounds the clumsiness of the original, and too often the translator gets the blame that should fall on the originator.

\section{CONCLUSION}

The formation of the Interpreter Corps in the early seventies was a bold venture. There is no doubt that the provision of simultaneous interpretation in the Legislative Assembly and in countless community meetings has been an invaluable factor in making government relevant and accountable to the people of the NWT. But as I look back over the years since the Interpreter Corps was formed, and consider all the hours those talented young native people have spent toiling to turn turgid transient government prose into something intelligible in the communities, I begin to wonder what would have happened if a minute fraction of that energy and expense had been permitted to flow into the translation of material of enduring cultural relevance. Father Guy-Mary Rousselière's Qitdlarssuaq, the epic story of the journey of a group of Canadian Inuit to no07rthern Greenland, is being translated from French into English, but not into Inuktitut. Dorothy Eber's fascinating and valuable history of Arctic whaling from the Inuit perspective is available only in English. Those are only two examples from a very long list. The skills and experience concentrated in the Language Bureau are too valuable to be restricted to such a narrow channel of communication. Maybe it's time for someone with vision to give the Language Bureau a mandate as broad as its title. 